\title{
New Public Management and Developmental State: Revisiting the Institutional Imperatives in Nigeria
}

\author{
Jide Ibietan, PhD \\ Segun Joshua, PhD \\ Department of Political Science and International Relations, Covenant University, Ota, Ogun State, Nigeria \\ Olajide.ibietan@covenantuniversity.edu.ng; segun.joshua@covenantuniversity.edu.ng
}

Doi:10.5901/mjss.2015.v6n3s2p58

\begin{abstract}
The main objective of this paper is to highlight that the effective application of the New Public Management (NPM) reform initiatives can galvanise the actualisation of the developmental state aspiration of the Nigerian state. The dysfunctions of the traditional paradigm of public administration/bureaucracy which made it grossly inadequate in realising the developmental drives in Nigeria were identified. The utilisation of secondary data which were textually analysed and logically validated, together with the adoption of public choice theory as framework of analysis informed the position of the paper that pragmatic reform initiatives and effective institutions are required to bifurcate the routine public service reform exercises which Nigeria has been grappling with since 1934. A radical departure from bureau-pathologies must be purposely contemplated and the reform orientation of the New Public Management has the potency of redressing this challenge. The combination of this with the appropriate institutional imperatives can catalyse and capacitate the Nigerian Public Service as effective agent of development in Nigeria.
\end{abstract}

Keywords: New Public Management; Development; State; Institution; Imperatives

\section{Introduction}

Emerging views from contemporary literature in the field of public administration have crystallised into a conclusion that the traditional paradigm of public administration has proved quite inadequate in transforming post-colonial states into development-oriented states. To be sure, Olaopa (2008: 55) documented the features of the old bureaucratic paradigm as follows:

Emphasis is placed on the need of the organisation, thus making it an end in itself; hierarchical with emphasis on control and compliance; authority and control are centralised; emphasis is on continuity and stability; programmes are budget-driven (and) financed largely by appropriation; it is based on the idea of government monopoly on service delivery.

It is perhaps based on the above that some scholars canvassed the need for development-oriented public bureaucracy and effective institutions to play crucial roles. This argument extends to posit that the basic goals of the Nigerian public service inherited from the British Colonialists were to ensure the political dominance and control of the state through maintenance of law and order, and advancing the economic interest of the metropolitan power (Adamolekun, 2006; Umaru, 2013; Ibietan and Oni 2013).

A developmental state must necessarily play proactive roles through the creation of enabling environment for private sector participation in the economy, and deliberate efforts by tiers and agencies of government to galvanise socioeconomic and political development via the utilisation of human and other resources. The old or traditional paradigm of public administration has proved fundamentally deficient in achieving this. Thus, a rethink of and the need to tinker with the features of bureaucracy anchored on Weberianism cannot be overemphasized. This forms the essence of the New Public Management (NPM) as reform initiative that can bolster public service effectiveness in Nigeria, and ultimately lead to a developmental state with the public bureaucracy in Nigeria as an agent and catalyst of development.

It is germane to state that the Nigerian civil/public service which came into existence in 1954 had witnessed a litany of reforms and as corroborated by Olaopa (2014: 89), "... these reforms have been directed more towards damage control rather than a positive reappraisal of the original objectives of the civil service as an institution." The explanations for this state of affairs are not far-fetched. From inception, the attempt to graft a foreign structure on local realities presented the bureaucracy with problems which successive reforms sought to attenuate and the consequences had been 
largely reverberating. It is also consistent with good reasoning to state that the Nigerian public service is still an evolving institution on the journey towards maturity. These underscore the need to build and strengthen institutions anchored on leadership values, processes and to leverage institutional capacities for effective service delivery and development outcomes.

This paper is divided into six sections. The first part is the Abstract; followed by Introduction; Literature Review in which the New Public Management, Development/Developmental state are conceptualised; public choice theory as framework of analysis for the paper is within the purview of this section; Methodology; Results and Discussion on Nigeria's Developmental Status via the old paradigm of public sector management and the Institutional Imperatives of NPM in the Nigerian Public Sector are discussed. The final part is devoted to Conclusion and Recommendation.

\title{
2. Literature Review
}

This section takes on the concepts of New Public Management; Development/Developmental state; and public choice theory as framework of analysis for this paper.

\subsection{Conceptualising New Public Management}

The changing perception on the role of the state in governance and public affairs has led to critical thinking and assault on public bureaucracy anchored on the traditional paradigm of the Weberian model as an effective institution for service delivery (social/public goods) and in the development process of nation-states. It is perhaps quite illuminating that Adamolekun (2002: 14) explained thus:

\begin{abstract}
... NPM seeks to apply market principles to governmental administration, with an emphasis on competition, contracting and customer orientation. It also emphasizes merit-based recruitment and promotion ... increased autonomy for managers ("letting managers manage") with corresponding responsibility, performance-related pay...continuous skills development and upgrading. There is also an emphasis on performance measurement, with particular attention to the delivery of services to the public.
\end{abstract}

The underlining tenets of NPM are as follows: management orientation, efficiency and performance enhancing measures based on objective and timely appraisal; leaner public bureaucracies in form of agencies that are driven by market principles such as contracting out (out-sourcing); competition; cost-reduction measures; setting benchmarks and targets; short-term contracts; financial inducement and guaranteeing wider latitudes of discretion for managers. To be sure, NPM connotes the application of business philosophy, principles and practices to governmental activities.

In underscoring the above averments, Sharma, Sadana and Kaur (2012: 46) posited that NPM presupposes that "government should not be both provider ... (and) producer. The government should produce nothing at all." They corroborated that Government should regulate and create proper environment for free enterprise and competition, preferably through outsourcing. A common thread or denominator linking the foregoing conceptualisation of NPM is the business style or approach to public sector management. Sharma et al (2012) posited further that NPM is essentially marked by a more forthright and honest consideration of the interdependence between administrative structures cum processes and their corresponding ends and goals, this reinforces the relevance of institutions in service delivery and ultimately in the realisation or yearnings of a developmental state.

Umaru (2013: 244) building on other scholars identified four components of NPM as: efficiency drive with the objective of making the public sector more business-like; downsizing and decentralisation which focuses on disaggregation, organizational flexibility and rightsizing; management change that is devoted to integrating bottom-up and top down approaches to change based on service quality. The latter part of this characterisation of NPM converges accurately with the position taken by Sharma et al (2012: 43) that NPM like Development Administration is goal and change oriented, but more importantly focuses on processes that make public sector organisations more positivist and activist. Umaru (2013) corroborated that NPM is a global phenomenon underscored by a paradigm shift from traditional public administration and it is driven conjointly by socio-economic, political and technological factors.

Stretching further the works of scholars like Obi and Nwanegbo(2006), Ibietan (2013: 57) documented these factors as underscoring NPM: decentralised decision making; cost recovery; alternative service delivery; performance contracting; commercialisation; citizens charter and public reporting. An explication of the institutional imperatives of these in achieving a developmental state (status) for Nigeria is reserved for another section of this paper under Results and Discussion. 


\subsection{The Concepts of Development/Developmental State}

Attempts at defining or conceptualising development have been seriously underpinned by semantic problems as well as the divergent philosophical and ideological orientations of writers and scholars as academics or practitioners. For instance, Sen (1999) conceptualised development from the ends and means of freedoms. To him, freedom is a primary end and principal means of development, any developmental effort that misses these variables is off the course, and he captured it as the constitutive and instrumental roles of freedom.

Todaro (1982) in Okoli and Onah (2002: 130) defined development thus:

A multi-dimensional process involving the re-organization and re-orientation of the entire economic and social system. This involves, in addition to improvement of income and output, radical changes in institutional and administrative structures as well as in popular attitudes, customs and beliefs.

Implied in the above definition is the fact that development is not only a physical process, but extends to incorporate behavioural or attitudinal changes required for vigorous institutional transformation. The net effect of this is the positive impact on the socio-cultural, economic and politico-administrative systems of the nation-state manifesting in improved education, health care delivery, housing, infrastructures and other public/social services.

Apeh (2007: 86) operationalised development as follows:

Quantitative and qualitative changes and increase in the structure, composition and performance of the forces of production. It is predicated on the enhancement of freedom and improvements in the standard of living of members of the society through the eradication of illiteracy, disease, hunger and poverty.

The latter part of the above definition converges with that of Sen (1999) which finds expression in the central role of freedom in the development process and outcome. Development therefore reinforces allocative efficiency and distributional equity of public goods and social services which produces trickle-down effects. This way, the common man becomes the focus of development with noticeable life-changing improvements.

From the foregoing and the contributions of other scholars on this subject, it is obvious that the definition of development tends to assume a clear movement away from the conventional economic indicators (of increase in GDP, GNP, per capita income and others) to non-economic indices such as the democratic and institutional imperatives of political governance and social indicators (Jhingan, 2007: 5-12).

The term "Developmental State" is traceable to the writings of international political economy scholars which refer to attempts or efforts in the late twentieth century by governments in Eastern Asia to usher in development through centralised or state-led macroeconomic planning.

Leftwitch (1995) in Tomwarri (2011: 319) conceptualised a developmental state this way:

... has more independent, or autonomous political power determined developmental elite; a powerful, competent and insulated bureaucracy; a weak and subordinated civil society; the effective management of non-state economic interests; legitimacy and performance, strategic capacity, organisational and technical capacity to play its developmental role.

The wholesale adoption of the above definition requires a great deal of care and caution. This is predicated on some gaps and codicils inherent in it. To be precise, the inclusion of a weak and subordinated civil society as a feature of developmental state portrays totalitarianism and fascism. It also gives the erroneous and unintended implication that a developmental state cannot be democratic, otherwise, how can one rationalise this proviso of weak and subordinated civil society. Indeed, a vibrant and active civil society is one good platform for entrenching democratic practice. The addition of "the effective management of non-state economic interests" presupposes that state economic interests and public services/social goods do not require effective management, and this is quite naïve and misleading.

A developmental state can be construed as:

one whose ideological underpinnings are developmental and one that seriously attempts to deploy its administrative and political resources to the task of economic development and as states whose politics have concentrated sufficient power, autonomy and capacity at the centre to shape, pursue and encourage the achievement of explicitly developmental objectives, whether by establishing and promoting the conditions and directions of economic growth, or by organizing it directly, or by a varying combination of both (Mbabazi and Taylor 2005: 2, 5). 
It is deductible from the above definition that the focus and motivation of a developmental state are economic growth and development using political and administrative resources. The institutional imperative in this cannot be overemphasized. The only snag in this definition is the argument for undue centralisation of power, autonomy and capacity which could hamper rapid and urgent dispersal of developmental benefits in emerging and post-colonial states like Nigeria.

The contributions of Adamolekun (2006: 94) on a related theme show that a developmental state seeks to bring about a qualitative improvement in the standard of living of its citizens by "promoting industrialization, agricultural development, the construction of roads, railways and other transport facilities and providing social and welfare services" The instrumentality for attaining this goal, especially by some post-colonial African states was located in developmentoriented public bureaucracy realisable through administrative reforms. However, Adamolekun (2006) noted that an objective assessment of the prevailing realities in most of these states shows that the administrative reforms have not produced the desired results.

The institutional and other reform imperatives inherent in NPM offer necessary platforms to redress the above dysfunctions at the heart of traditional public administration bolster public service delivery/effectiveness and galvanise development. Can Nigeria be defined as a developmental state? The concomitant juxtaposition of affluence and affliction in the words of Ibeanu (2008) is a testimony that Nigeria is not yet a developmental state. This is underscored by the elite complicity in resource mismanagement, political activities and governance underlined by plunder, combined with leading policy outcomes that are not only unfair but inequitable to the mass of the citizenry.

\section{Theoretical Framework: Public Choice Theory}

This paper has its theoretical base laid in the Public Choice Theory. This theory benefited greatly from the works of scholars like Self (1972); Dunleavy (1991); Stover (1991); Pirie (1992); Krueger (1993); Chandler (1994); Das (1998); Adamolekun (2002); Ezeani (2004); and Olaopa (2008). The main thrust of this theory is that market considerations offer the optimal mechanism for service delivery and decision making.

The theorists similarly contend that public bureaucracies and representative democracy have in-built tendency to over-supply due to numerous factors which include the inclination of political office holders to conceal the true economic and fiscal positions of the country from the electorates and a resort to deficit financing in order to keep electioneering promises. The theory also posit that organised interest groups and bureaucrats constantly push for more and advance selfish narrow interests to the detriment of the silent and disorganised masses that fund state expenditure (Stoker, 1991:239).

A further contention of the theory is that the existing democratic arrangements are poor predictors of citizens' preferences and demands (Ezeani, 2004:49). The failure of representative democracy and public bureaucracies create in-built tendencies for profligacy and inefficiency on the part of government. The theory asserts that, government can be too big, disconnected from the people, unnecessarily politicised and hijacked by vested interests. Predicated on this, government tends to ignore citizens preferences which results in oversupply of low quality and irrelevant services.

The relevance of this theory to governance and the management of public affairs in Nigeria cannot be overemphasized. The poor state of infrastructures, social sciences and delivery of essential public goods in the face of abundant human and material resources shows a yawning gap between resource endowment and management on one hand, and development outcomes on the other. This realisation calls for appropriate administrative and institutional reforms located in the tenets of public choice theory and the pragmatic application of NPM initiatives.

The complicity of the governing elites in Nigeria in resource mismanagement with deep seated manifestations of avarice and rapacious tendencies has led scholars to describing Nigeria as a predatory autocracy characterised by policy instability, underdeveloped economic infrastructure and very scarce provisioning of public goods (Eifert, Gelb and Tallroth, 2003; Tomwarri; 2011). To halt this regression and position Nigeria on a fast lane to attaining the status of a developmental state would require determined political will at strengthening institutional capacity and drive that can severe the present romance with corruption and sundry acts of graft in the public domain.

The argument of public choice theorists that government can be too big, disconnected from the people, unnecessarily politicised and hijacked by vested interests, ignoring citizens preferences resulting in low quality or irrelevant services is very apt in Nigeria. An objective appraisal or performance evaluation of the political class since the re-emergence of democracy in 1999 reveal serious infrastructural deficits, mounting security challenges/insurgency which has made life very cheap and unpredictable in Nigeria, and poor social services delivery to mention but a few. The narrative presents a very disturbing picture as the mass of Nigerians had experienced raw deal from the governing elites in place of the much desired dividends of democracy. Appropriate remedial measures to the above dysfunctional state of 
affairs should be found in institutional reforms backed by techno-managerial expertise inherent in the public choice theory and the tenets of the NPM.

\section{Methodology}

The paper benefitted mainly from secondary sources of data which were textually analysed and logically validated. Logical validation was employed in guaranteeing the validity of findings, discussion and recommendations of this paper. Logical validation according to Obasi (1999:121) is a careful attempt at ensuring that the contents of the research instrument is based on theoretical knowledge in the field being studied "and by convincing oneself that commonsensically, the items.... in the instrument are logically reflective of what is being studied..."

The secondary data utilised in this paper, which were subjected to textual analysis and backed up by public choice theory as analytical framework with a focus on the objective of this paper are of theoretical and practical relevance, thus being logically reflective of the theme of this paper. The convenience, generalizability and efficacy of the instruments of data collection and analysis informed the deductions made and strengthened the recommendations proffered.

\section{Results and Discussion}

\subsection{Appraising Nigeria's Developmental Status: Traditional Paradigm of Public Sector Management and the Institutional Imperatives of NPM}

Juxtaposing Nigeria with indicators of developmental state highlighted earlier brings to the fore, the fact that Nigeria cannot be classified among the developmental states. This is evident in the growing gaps between the rich and the poor; shrinking public service; inaccessibility to public goods; economic decline; growing levels of corruption; unaccountable political system; policy instability and somersaults that are quite discouraging to foreign investment in spite of the large domestic market and the strategic location of the country among others. Little wonder that Ezema and Ogujiuba (2012) posited that the developmental state paradigm (DSP) is at present far from being realised in Nigeria. In the same vein, the World Bank (2010) observed that the Nigerian system has broken down and the economy has failed. This scenario has culminated in unprecedented distortion and inequality in income distribution with implication for high level of poverty which has been put at $70.8 \%$. The World Bank yardstick for defining the poor is any person earning or spending less than $\$ 1$ a day. From the angle of per capita income, Nigeria ranks 160 out of 177 . Life expectancy in Nigeria is put at an average of 46 years (World Bank, 2010).

Building on Abdullah and Dyk-Robertson (2008), the aforementioned ills and many others are attributed to the dysfunctional and poorly developed public bureaucracy. Suffice to say that effective and efficient bureaucracy is a necessary condition for attaining developmental state. This is in line with the position of Ezema and Ogujiuba (2012) that a developmental state must have the bureaucratic capacity to advance development. The Nigerian public bureaucracy lacks the capacity to galvanise development because the traditional paradigm of public sector management is still very much in vogue which has been explicated earlier in this paper, coupled with some ills associated with bureaucratic practices in Nigeria which was underscored by Okafor (2005:67) thus:

Once ensconced in a bureaucratic position, officials are promoted primarily on the bases of seniority. Rules for promotion fail to differentiate between productive and non-productive workers. Dismissal is rare except during the mass purge of Murtala-Obasanjo administration in 1975-1976, it is hard to lose a government job in Nigeria.

In addition, from the perspective of personnel qualifications, employees at the point of entry into the public and civil services often through the spoils system are mostly deficient in technical skills for their positions. It has also been discovered that on-the-job training programmes are weak and ineffective. The result of this process is that emphasis is placed on filling slots without recourse to whether employees' skills match the needs of such positions (Eme and Ugwu 2011).

Some of the ills associated with the management of the Nigerian public sector under the traditional paradigm can be gleaned from the work of Dike (1985). The author identified; poor organization, over-staffing, over-centralization, apathy, resistance to change, corruption, red tape, incompetence, favouritism as some of the factors bedevilling the Nigerian bureaucracy and thus, hamper its effectiveness.

\subsubsection{Poor Organization}

The Nigerian public bureaucracy lacks a scientific work system. This is evident in the fact that most Nigerian civil servants 
have modicum knowledge of the goals of the service or those of governments in which they serve. It is observed that even when it seems they have clear ideas of individual assignments (which is not always), they often lack understanding on how these assignments relate to one another and to the larger goals of government. This situation makes job description imprecise and overlapping. Even the result-oriented management approach that is much talked about tends to be an academic exercise and quite mechanistic.

\subsubsection{Over-Staffing}

One bane of performance in the Nigerian public bureaucracy is traceable to over-staffing; this problem is predicated on lack of proper study of staff requirements of public bureaucracy vis-a-vis the actual functions to be performed. In the Nigerian context, civil servants are recruited without consideration for service needs. It is not an overstatement to say that quite a number of staff in many ministries, departments and agencies of government are grossly underutilised because of this.

\subsubsection{Over-Centralization}

Little consideration is given to delegation of authority within the service. This situation has created reluctance on the part of subordinate officers to use their initiative in the performance of their duties. The net result is that, while top level officers are over-worked as they grapple with both policy and routine matters, junior officers are underutilised.

\subsubsection{Apathy}

This is a carry-over of the colonial experience with the mentality that government's job is nobody's job, and as such, there is less concern for productivity.

\subsubsection{Resistance to Change:}

The Nigerian public service in particular is still conservative, inflexible and intolerant to change, and it has become very difficult to imbibe modern approaches to public sector management.

\subsubsection{Corruption}

This has become very cancerous in the management of public affairs in Nigeria, as legitimate duties in the public bureaucracy are either perfunctorily executed or done at a cost to the recipient, thus making the interest of the public, not truly served.

\subsubsection{Favouritism}

In one sense, favouritism is similar to corruption, because it involves doing someone a service contrary to the rules. While corruption is perpetrated for material considerations (whether past, present, or future), favouritism may be shown in order to maintain influence, to secure friendship, or for other self-serving reasons.

\subsubsection{Red tapes}

Simply denotes rigid adherence to rules and procedures, which may involve interminable filling of forms, multiple approval and endorsement requirements, extended consultations and such other processes that cause delays and inconveniences crystallising in irritation and frustration to the public.

The above was corroborated by Eme and Ugwu (2011) that the problems confronting the public bureaucracy in Nigeria can be discussed under structural, administrative and behavioural, political and economic respectively. Some of the aforementioned problems can be captured under personnel qualifications, organizational structure, procedures for promotion and dismissal among others.

In their views, Abdullah and Dyk-Robertson (2008) adduced traditional high-handedness and omniscient tendencies of officials; incompetence; disempowerment of ordinary people through the officious language typically being used; asking for bribes in anticipation of services required; tardiness; and their exclusive hold on information as power 
over the ordinary citizens. The foregoing makes the Nigerian public bureaucracy incapable of galvanising development. Agagu (2008:243) posited that "the public service which was seen as the custodian of rules and regulations and the engine of development had lost its prestige and confidence".

Obasanjo (2004 cited in Thovoethin, 2014: 266) aptly described bureaucracy and technocracy in Nigeria thus:

Over the years, the public services at federal and state levels lost the value on which they were established. Merit is sacrificed for expediency and opportunism. Retraining of hired staff hardly take place. It allows so-called ghost workers to infiltrate the service and ended up with a pay-roll that is totally at variance with output or productivity, parastatals are so mismanaged, looted, and badly ruined that they became an embarrassment to norms of efficiency, productivity, management and probity... Proliferation of parastatals as well as the creation of several agencies had resulted in unnecessary duplication of functions and in some cases, mandates... The management of these agencies appointed persons into the public service haphazardly with the result that most of them are now over-bloated and enormous resources are spent on their overheads.

It is necessary to stress that the success of a developmental state rest squarely on professionalised public bureaucracy that feeds into policy formulation and implementation process efficiently (Eme and Ugwu, 2011). Evans (2003 cited in Thovoethin, 2014) contended that developmental state necessitates a stronger and autonomous state enhanced by a powerful, efficient and effective bureaucracy recruited from the best talents available in the state. That is to say, preference must be given to people with technical expertise in policy formulation and implementation in the drive for developmental state. Evans (2003) stressed further that the idea of developmental state puts robust, competent public institutions at the centre of the development matrix. To be sure, Jayasuriya (2006) underscored the importance of bureaucracy in developmental efforts by asserting that institutions become the key to explaining development outcomes (of which the public service institution is crucial). Amuwo (2007:11) corroborated this part of the analysis thus: "without a seasoned and development-oriented bureaucracy, state interventionism would, in all probability, amount to little more than the unwitting transfer of public resources to local capitalist class"

Predicated on this, there is a need to tinker with the employment process based on competency, merit, wellstructured and motivated bureaucracy/technocracy which will strengthen the drive for developmental state. This should be skewed in favour of the tenets of New Public Management which will serve as a launch pad. Some of these tenets as explicated by Ibietan (2013:58) are:

\subsubsection{Decentralization}

Proponents of the NPM have argued that centralization is costly due to inflexibility. This engenders red tapes, rigidity which conspires to hamper effectiveness in service delivery. Decentralization creates room for initiatives and the latitude for officials to manage their units for better performance.

\subsubsection{Cost-Recovery}

Public-Private Partnership is one platform of NPM anchored on Build, Operate and Maintain (BOM), like re-introducing toll collection so as to reduce the cost of maintaining social services like roads among others. Although, it is argued that this reform initiative will take such services away from the poor, the effect can be cushioned through an effectively managed subsidy programme.

\subsubsection{Alternative Service Delivery}

This emphasise the need for government to focus on its areas of core competence in the provision of services for the populace which can be realised through Public-Private Partnership (PPP).

\subsubsection{Performance Contracting}

There is the need for government agencies, public service and government ministries to clarify objectives in such a way that evaluation, accountability and service effectiveness are measured.

\subsubsection{Commercialization}

A number of governments have fraternised with the idea of commercialising non-performing public enterprises so as to 
enhance efficiency which should translate to development as one of the platforms of NPM, the failure of this is seen in lack of transparency in the entire process.

\subsubsection{Citizen Charter}

One of the distinguishing marks of traditional public administration in comparison to the NPM lies in the way it perceives clients which also reflects in the approach to service delivery. The NPM approach to public sector management sees individuals as customers who should be treated as "kings". However, the traditional public administration sees the public as being at their mercy. This attitudinal inclination of traditional public administration explains the lack of effectiveness in service delivery with implications for development.

\subsubsection{Public Reporting}

One major lever around which NPM revolves is accountability and transparency in the conduct of government business. This is made possible via access to information, especially on financial matters in the public domain. The effective application of the Freedom of Information Act should rise to this demand, and position the public bureaucracy as proactive agents of development.

\section{Conclusion and Recommendations}

The central argument of this paper is that the Nigerian public bureaucracy can be positioned for effective service delivery and be proactive agent of development for the Nigerian state. This is realisable through the reform inclination of the New Public Management which seeks to remedy the gaps and failings of the old paradigm of public administration. The framework of analysis anchored on public choice theory and the tenets of NPM invigorated the submissions and positions taken in this paper, upon which the following recommendations are proffered:

A developmental state would require the conscious transformation of the political and bureaucratic elites from predatory to positivist, activist and developmental orientation in their approach to governance and the management of public resources/affairs.

A further decentralisation of the political and administrative structures for rapid and enhanced delivery of public services and democratic dividends with trickle-down effects is seriously canvassed.

The new initiative for institutionalising public service reforms should be retained and sustained, in order to permanently arrest the conception-reality gaps that characterise successive reform efforts/activities.

Conscious attempts should be made to build and sustain enduring political and administrative institutions for effective service delivery in the public sector. This would serve as prelude to and catalyst for the realisation of the much desired developmental state status for Nigeria.

An entrenched and further professionalised public bureaucracy anchored on techno-managerial expertise and rationality as precursor to developmental state is highly recommended.

\section{Acknowlegment}

The authors are grateful to Covenant University Centre for Research, Innovation and Discovery (CUCRID) Ota-Nigeria for the funds released for the publication of this research.

\section{References}

Abdullah, S.A. and Dyk-Robertson, H.V. (2008). Enhancing the Performance of the Public Service in a Developmental State: A Country Study of Nigeria. A Paper Prepared for the 2008 AAPM Roundtable, October, Accra, Ghana

Adamolekun, L. (2002).Governance Context and Reorientation of Government. In Adamolekun, L. (Eds.),Public Administration in Africa: Main Issuesand Selected Country Studies (pp 3-16). Ibadan: Spectrum Books Limited.

Adamolekun, L. (2006). Politics, Bureaucracy and Development in Africa. Ibadan: Spectrum Books Limited.

Agagu, A.A. (2008). Re-inventing the Nigerian Public Service in An Era of Reforms. Pakistan Journal of Social Sciences, 5(3):244-252.

Amuwo, K. (2008). "Constructing the Democratic Developmental State in Africa: A Case Study of Nigeria, 1960-2007", Institute for Global Dialogue Occasional Paper No. 59

Apeh, I. E. (2007).Public Enterprises and Crisis of Development in Nigeria: 1960 to 2006.Journal of International Politics and Development Studies, University of Nigeria, 
Nsukka, 3(1), 83-97.

Asogwa, M. N. O. (2009). Public Service and Market Mechanism: Competition Contracting and the New Public Management. Nigerian Journal of Public Administration and Local Government, UNN, 14 (1\&2), 362-377.

Dike, C. (1985). The Nigerian Civil Service. Owerri: Alfa Publishing Company.

Eifert, B., Gelb, A.,\&Tallroth, N. (2003). Managing Oil Wealth. Finance and Development, 40 (1).

Eme, O.I and Ugwu, S.C. (2011). Developmental State Bureaucracy in Nigeria: Restructuring for Effectiveness (1999-2007). Arabian Journal of Business and Management Review (OMAN) 1(5): 96-113

Ezeani, E. O. (2004).Local Government Administration. Enugu: Zik-Chuks Publishers.

Ezema, B. I. and Ogujiuba, K (2012). The Developmental State Debate: Where Is Nigeria? Journal of Sustainable Development, 5 (1):100-113 January.

Ibeanu, O. (2008, February). Affluence and Affliction: The Niger Delta as a Critique of Political Science in Nigeria. An Inaugural Lecture of the University of Nigeria, Nsukka.

Ibietan, J. (2013). New Public Management and Public Service Effectiveness in Nigeria: A Pragmatic Discourse. Public Policy and Administration Research, International Institute for Science, Technology \& Education, USA. 3 (7), 53-61.

Ibietan, J. and Oghator, E. (2013).Trends in Development Planning in Nigeria: 1962 to 2012.Journal of Sustainable Development in Africa, Clarion University of Pennsylvania, USA, 15 (4), 297-311.

Ibietan, J. and Oni, S. (2013). The Weberian Bureaucratic Principles and Nigerian Public Bureaucracy: An Evaluation. The Quarterly Journal of Administration, OAU, lle-lfe, 33 (2) 31-51.

Jayasuriya, K. (2006). "Beyond Institutional Fetishism: From the Developmental to the Regulatory State", New Political Economy, 10 (3):

Jhingan, M. L. (2007). The Economics of Development and Planning. Delhi: Vrinda Publications (P) Ltd.

Mbabazi, P. and Taylor, I. (2005).Botswana and Uganda as Developmental States in Africa: Botswana and Uganda Compared. Dakar: CODESRIA.

Obasi, I.N. (1999). Research Methodology in Political Science. Enugu: Academic Publishing Company.

Obi, E. A. and Nwanegbo, C.J. (2006).Development Administration: Theory and Applications. Onitsha: Bookpoint Ltd.

Okafor, E.E. (2005). "Public Bureaucracy and Development in Nigeria: A Critical Overview of Impediments to Public Service Delivery" CODESRIA Bulletin, Nos. 3-4

Okoli, F. C. and Onah, F. O. (2002).Public Administration in Nigeria: Nature, Principles and Application. Enugu: John Jacob's Classic Publishers Ltd.

Olaopa, T. (2008). Theory and Practice of Public Administration and Civil Service Reforms in Nigeria. Ibadan: Spectrum Books Limited.

Olaopa, T. (2014, June 29). Public Service Administration in an Era of Open Government. ThisDay, p.89.

Sen, A. (1999).Development As Freedom. New York: Anchor Books.

Sharma, M. P., Sadana, B. L.,\&Kaur, H. (2012).Public Administration in Theory and Practice. Allahabad: KitabMahal.

Stoker, G. (1991). The PoliticsofLocal Government. London: Macmillian.

Thovoethin, P (2014). Techno-Bureaucratic Governance and Developmental State in Africa: Botswana and Nigeria in Comparative Perspective. European Scientific Journal Special edition 257-273August.

Tomwarri, E. (2011). The Developmental State in Africa: Interrogating the Nigerian Status. Nigerian Journal of Administrative Science, UNIBEN, Benin City, 9 (1\&2), 314-335.

Umaru, U. D. (2013). "The New Public Management Reform Approach and Tenure Policy in the Nigerian Public Service". In Nigerian Journal of Administrative Science, UNIBEN, Benin City, 10 (1\&2). 238-255

Umaru,U. D. (2013). "An Assessment of the New Public Management Reform Approach on Privatization Programme in Nigeria".In Nigerian Journal of Administrative Science, UNIBEN, Benin City, 10 (1\&2) 198-219

World Bank (2010) World Development Indicator and Global Development Finance. 